\title{
Prevention and Adjuvant Therapy of Recurrent Respiratory Papillomatosis
}

\section{Dong Kun Lee (iD)}

Department of Otolaryngology-Head and Neck Surgery, Dong-A University College of Medicine, Busan, Korea

재발성 호흡기 유두종증의 예방과 보조 요법

이동근

동아대학교 의과대학 이비인후-두경부외과학교실

Recurrent respiratory papillomatosis (RRP) is characterized by repeated recurrence in the respiratory system, such as the pharynx, larynx, and trachea, caused by the human papilloma virus. The main treatment is surgical removal of the papilloma. However repeated recurrence of RRP in multiple areas is burdened for the surgeon. In addition to the surgery, various adjuvant therapies have been studied to reduce the recurrence. Literature review was conducted with a focus on the adjuvant treatments for RRP.

Keywords Adjuvants; Human papillomavirus; Recurrent respiratory papillomatosis; Papillomavirus Vaccines.

\section{서 론}

재발성 호흡기 유두종증은 미국에서 발생률(incidence)이 10만명 당 14세 이하 소아 에서 4.3명, 성인에서 1.8 명으로 비교적 드물 질환이다. 하지만 재발성 호흡기 유두종증 의 유병률은 여성에서 점점 증가하고 있다. 14 59세 여성에서는 $26.8 \%, 20 ~ 24$ 세 여성에 서는 $45 \%$ 로 보고된다. ${ }^{2}$ 재발성 호흡기 유두종증을 일으키는 원인은 인유두종바이러스 (human papilloma virus)로 de-oxyribonucleic acid(DNA) 바이러스로 작은 상처 등을 통해 피부나 생식기, 상부호흡기계, 구강 점막의 기저상피층(basal epithelium)에서 감 염을 일으킨다. 어른에서 재발성 호흡기 유두종증이 발생되는 경우는 구강이나 생식기 를 통한 성적 접촉으로 감염되었거나 또는 출산 때 모태 감염이 잠복기로 있다가 증식 하여 발생할 수 있다. ${ }^{3)} 170$ 여 종 이상의 형이 있으며 재발성 유두종증을 일으키는 가장 흔한 형(type)은 인유두종바이러스 6과 11이 약 90\%로 대부분을 차지한다. ${ }^{2)}$ 인유두종 바이러스 11 은 6 보다 임상 양상이 더 심하게 발현되는데, 발병이 더 일찍 시작되며 질병 이 더 오랜 기간 지속되고 기관이나 폐의 침범 빈도가 높으며 기관절개술을 시행해야 하 는 경우가 많다. 따라서 수술적 치료도 더 많이 필요하며 사망률도 높고 악성화되는 경

\author{
Received June 1, 2020 \\ Revised June 9, 2020 \\ Accepted June 12, 2020

\section{Corresponding Author} \\ Dong Kun Lee, MD, PhD \\ Department of Otolaryngology- \\ Head and Neck Surgery, \\ Dong-A University \\ College of Medicine, \\ 26 Daesingongwon-ro, Seo-gu, \\ Busan 49201, Korea \\ Tel +82-51-240-5428 \\ Fax+82-51-253-0712 \\ E-mail chaos001@hanmail.net
}

\section{ORCID iD}

Dong Kun Lee (iD)

https://orcid.org/0000-0002-7296-1420

This is an Open Access article distributed under the terms of the Creative Commons Attribution Non-Commercial License (https://creativecommons.org/ licenses/by-nc/4.0) which permits unrestricted non-commercial use, distribution, and reproduction in any medium, provided the original work is properly cited. 
우가 더 흔하여 예후가 좋지 않다.4) 인유두종 바이러스 6과 11 이 동시 감염되는 경우가 발견되기도 한다. 인유두종바이러 스 16,18 은 악성 가능성이 인유두종바이러스 6,11 보다 더 높 은 것으로 알려져 있다. 그리고 단순헤르페스바이러스(herpes simplex virus), 거대세포바이러스(cytomegalovirus) 그 리고 엡스타인-바바이러스(Epstein-Barr virus) 등의 감염이 함께 발생하면 더욱 심한 임상 양상을 띄게 된다. 이러한 인유 두종바이러스의 난치성 임상적 특성으로 인해 수술 이외 보 조적인 치료법들의 필요성이 높기 때문에 다양한 시도와 연 구가 지속적으로 이루어지고 있다. 본 연구에서는 보조적인 치료법들에 초점을 맞추어 기술하고자 한다.

\section{본 론}

보편적으로 재발성 호흡기 유두종증에서 수술적 치료와 더 불어 보조요법을 시행하는 경우는 1) 연 4회 이상 수술이 필요 할 때, 2) 재발의 간격이 빠르고 호흡장애를 유발할 때, 3) 원거 리와 다발성으로 발생하는 경우들이다. ${ }^{5)}$ 미국에서는 약 $20 \%$ 의 재발성 호흡기 유두종증 환자들에게 보조요법이 이루지고 있다.) 보조 치료의 종류는 celecoxib, 인후두역류증의 치료(H2 blocker 또는 proton pump inhibitor), 볼거리 백신(mumps vaccine), 인터페론(interferon), 인유두종바이러스 백신, 광역 학치료(photodynamic therapy), cis-retinoic acid, bevacizumab, 항바이러스제(cidofovir) 등이 있다. 재발성 호흡기 유 두종증에 대해 아직 완치적인 방법은 없지만 치료의 목표는 수술적 제거를 주요 치료법으로 하여 정상적인 구조를 보전하 여 음성의 질을 향상시키고 유두종을 가능한 모두 제거하여 기도 폐쇄를 해결하는 것이다. ${ }^{7}$

\section{Celecoxib}

Celecoxib은 cyclooxygenase-2-selective nonsteroidal anti-inflammatory drug으로서 관절염이나 통증 치료 목적 으로 흔히 사용되고 있다. 유두종에서 상피성장인자수용체와 cyclooxygenase-2와 prostaglandin E2의 발현이 증가되어 있 는 것을 기반으로한 치료 방법으로 cyclooxygenase-2를 억 제하여 유두종에 작용할 것으로 생각된다. Limsukon 등은 erlotinib와 celecoxib를 병용 투여하여 성공적으로 재발성 호 흡기 유두종증을 치료한 것을 보고하였다. Erlotinib은 상피 성장인자수용체(epidermal growth factor receptor)가 과발 현되어 있는 비소세포암 등에 사용되는 항암제이다. Celecoxib의 일반적 복용 지침에 따른 시작 용량은 하루에 1 회 400 $\mathrm{mg}$ 이고 유지 용량은 하루에 2회 $200 \mathrm{mg}$ 이지만, 연구에서는 하루 $400 \mathrm{mg}$ 과 $150 \mathrm{mg}$ 으로 사용하였다. Celecoxib의 효과에
대해서는 아직 장기간 연구 결과가 없고 항암제와 함께 투여 했던 연구 결과이기 때문에 임상에서 실제로 사용하기에는 제 한이 있으며, 아직 후속 연구가 활발히 이루지지 않고 있어 $\mathrm{ce}^{-}$ lecoxib의 치료 효과는 아직 불확실하다.

\section{인후두역류증의 치료(H2 blocker or proton pump inhibitor)}

인후두역류증은 위산으로 인해 인후두 점막의 손상을 일으 켜서 잠재적으로 유두종증의 증식과 확산을 일으킬 수 있기 때문에 재발성 호흡기 유두종증의 증상 악화나 치료 후 후두 협착이나 격막과 같은 합병증을 악화시키는 요인으로 알려져 있다.8) 재발성 호흡기 유두종증의 재발을 억제하기 위해 고용 량의 H2 blocker 또는 proton pump inhibitor를 투여하였을 경우 효과적이었다는 보고들이 있다. ${ }^{9-12)}$ 위산분비억제제는 최 대용량으로 투여한 경우가 많았으며 치료 효과와 방법에 대 해서는 보고가 부족하여 아직은 더 많은 연구가 필요하다. 일 반적으로 $\mathrm{CO} 2$ 레이저를 이용한 양성 후두 질환의 수술 후에 위산억제제를 흔히 임상에서 사용하고 있으며 큰 부작용이 없는 약물이기 때문에 경험적으로 임상에서 사용해 볼 수 있 다고 생각된다.

\section{볼거리 백신}

DNA 바이러스인 인유두종바이러스와는 다르게 볼거리바 이러스는 파라믹소 바이러스(paramyxovirus)에 속하는 ribonucleic acid(RNA) 바이러스이다. Pashley ${ }^{13)}$ 는 재발성 호흡 기 유두종증 환자에서 $\mathrm{CO} 2$ 레이저 수술 후 볼거리 백신을 국 소 병변내 주사를 시행하였고 38명의 환자를 대상으로한 시 험에서 29 명이 호전되었음을 보고하였다. 최근에는 26 명의 환 자를 대상으로 하여 전향적인 무작위 연구에서 수술 후 볼거 리-홍역-풍진 백신을 국소 도포하였을 때 유의미한 차이는 없었지만 재발 기간의 감소가 있었다는 보고가 있었다.14) 최근 에는 이와 비슷한 형태의 연구에서 볼거리-홍역-풍진 백신을 국소 도포한 경우에서 바이러스의 부하(load)가 낮거나 cidofovir를 사용한 대조군보다 치료에 효과적이라는 보고들도 있 다. ${ }^{15,16)}$ 볼거리 백신은 가격이 저렴하고 비교적 안전하며 쉽게 이용 가능한 장점이 있지만 아직 작용 기전에 대한 이론적 근 거와 효과에 대한 근거가 불충분하다.

\section{인터페론(Interferon)}

인터페론은 바이러스 감염과 같은 다양한 자극들에 대한 인체 반응으로 백혈구에서 분비되는 단백질로서 항체의 생산 을 증가시키고 면역세포들을 활성화시키는 기능을 하기 때문 에 바이러스의 증식을 억제하는 것으로 알려져 있다. 재발성 
호흡기 유두종증의 보조적인 치료로서 아주 초기 때부터 널 리 사용된 약물이다. ${ }^{17)}$ 근육내 주사를 통한 전신적인 투여가 필요하여 유두종증의 억제를 위해 장기간의 인터페론 투여는 가역적인 혈중 transaminase 상승, 백혈구감소중, 혈소판감소 증 등을 일으킬 수 있으며 환자는 일시적인 고열, 피로, 구토, 근육통, 두통 그리고 유아에서는 경직성 마비 등 흔한 합병증 이 발생할 수 있다.

인터페론이 유두종증의 재발을 감소시킨다는 보고들도 있 고 $^{18,19)}$ 장기간 치료에서 효과가 없었다는 보고도 있어 아직 논 란이 있다. ${ }^{20)}$ Maunsell과 Bellomo-Brandão ${ }^{19)}$ 는 소아 사례 에서 pegylated interferon을 $1 \mu \mathrm{g} / \mathrm{kg}$ 으로 1주마다 피하층으 로 6개월간 투여하였다.

Unmodified recombinant interferon-alpha는 더 이상 시 장에서 구할 수가 없어서 pegylated-interferon-alpha-2a로 대체되어 사용되고 있으며, Suter-Montano 등른 은 pegylated-interferon-alpha-2a와 granulocyte monocyte-colonystimulating factor 병합치료에서 11 명 환자 모두에서 12 개 월 간 재발이 없음을 보고하였다. 인터페론 치료에 반응이 있었던 환자들 중에서 인유두종바이러스 6이 11 보다 인터페 론에 더 반응이 좋다고 보고되어 바이러스 유형별로 치료 반 응에 대한 차이가 있는 것으로 보인다. ${ }^{22,23)}$ 전신적인 부작용 을 줄이기 위해 국소적인 인터페론을 사용하는 것에 대한 연 구도 이루어지고 있다. ${ }^{24)}$ 인터페론의 효과에 대해서는 아직 더 많은 연구가 필요한 실정이다.

\section{인유두종바이러스 백신}

인유두종바이러스 백신은 자궁경부암의 예방을 목적으로 널리 사용되어 왔으며, 최근에는 호흡기에서 발생하는 인유 두종에도 많은 연구가 이루어지고 있다. 4가(quadrivalent) 인 유두종바이러스 백신(Gardasil; Merck, Whitehouse Station, $\mathrm{NJ}, \mathrm{USA}$ )은 인유두종바이러스 $6,11,16,18$ 의 감염 예방하고, 2 가 백신은 인유두종바이러스 16,18 을 예방한다. 재발성 호 흡기 유두종증은 인유두종바이러스 6,11 에 의해 발생하므로 2 가 백신은 효과가 없다. 최근에는 9가 백신이 개발이 되어 인 유두종바이러스 $6,11,16,18$ 에 추가적으로 $31,33,45,52,58$ 의 예방이 가능하다.

백신의 투여 방법은 연령과 성별에 따라 회수와 접종 간격 이 조금씩 다르며 세부 사항은 다음과 같다. 4 가 백신은 만 9 13 세 사이 여아에게 필수 접종이며 6개월 간격으로 2회 접종 을 실시한다. 만 14 26세 이상 연령에서 첫 접종일 경우 0,2 , 6 개월 간격으로 3회 접종한다. 9가 백신은 만 9 14세 연령에 서 6개월 간격으로 2회 접종하며, 만 15 26세 연령에서 첫 접 종을 할 때는 $0,2,6$ 개월 간격으로 3 회 접종한다. 만약 1 차 접
종일 후 2차 접종 시기를 놓친다면 1년 이내에는 일정 변경이 가능하다. 2 차 접종은 최소 1 개월 간격, 3 차 접종은 최소 3 개월 이상의 간격을 지켜 접종 일을 변경할 수 있다. 이렇게 연령별 로 다른 백신 지침은 성경험이 없거나 적은 13 세 이하 연령일 때 인유두종바이러스 감염의 1 차 예방을 목적으로 바이러스 감 염 전 단계에서 막는 것이다. 성경험이 증가하는 14 세 이후에 인유두종바이러스 감염이 발생하더라도 재발성 유두종증이 나 자궁경부암 등의 중증의 질환을 막기 위한 2차 예방의 목 적으로도 접종을 권장하는 것으로 생각될 수 있다. 백신은 이 미 특정 인유두종바이러스 형에 감염되있더라도 다른 형의 바이러스로부터의 추가 감염을 예방하는 효과가 있다.

생식기나 호흡기계에서 인유두종바이러스 백신의 수술 후 보조요법의 효과에 대한 체계적 고찰에 따르면, 12 개중 9 개의 논문들에서 백신은 재발성 호흡기 유두종증의 재발과 질병 부 하를 낮추며 수술 간격이 늘어남을 보고 하였다. ${ }^{25)}$ Mészner 등 $^{26)}$ 은 증례 보고에서 인유두종바이러스 6,11 양성으로 수 술을 자주 받았던 환자가 인유두종바이러스에 대한 항체는 음성이었는데 인유두종바이러스 백신 투여 후에 항바이러스 항체가 형성됨을 확인한 사례를 보고한 바가 있다. 백신의 재 발성 호흡기 유두종에 대한 기전은 아직 알려지 있지 않기 때문에 치료적 목적으로는 그 효용성은 아직은 제한적이다. 백신 투여 후에는 자연 감염 상태보다 항체 수치가 훨씬 증가 되며 항체의 반응 또한 증가되기 때문에 백신의 인체 내에서 의 작용 기전은 면역원성(immunogenicity)을 증가시키는 것 으로 생각된다. 점점 여러 연구들에서 백신 투여 후에 유두종 증의 재발로 인하여 수술하는 빈도를 줄인다는 긍정적인 보고 들이 많이 있기 때문에 향후 연구가 더 활발히 필요하다.

\section{광역학치료}

광역학치료는 광감각제(photo-sensitizing agent)를 주사한 후 광원을 조사하면 조직의 산소와 서로 반응하여 광감각제가 활성화되어 세포독성을 일으키고 미세혈관을 손상시켜 증식 하는 세포를 파괴하는 방법이다. 주로 폐암, 식도암 등에서 사용되어 왔다. Shikowitz 등 ${ }^{27)}$ 은 동물실험에서 광역학치료 가 유두종에 효과가 있는 것을 확인한 후 재발성 호흡기 유두 종증에 대한 광역학치료를 1988년부터 시도하였다. 광감작제 로는 헤마토포르피린(hematoporphyrin) 유도체인 dihematoporphyrinether를 시술 48시간 전에 정맥으로 주사하였 다. 광원으로는 $630 \mathrm{~nm}$ 파장의 색소레이저(dye laser)를 사용 하였고 레이저 조사 시간은 100 200초였다. 총 48명에 대하여 치료군에서 $\mathrm{CO} 2$ 레이저는 기도를 확보할 정도로 최소한으로 사용한 후 광역학치료가 시행되었으며, 대조군은 고식적(conventional) 치료를 받은 33명이었다. 치료 결과 광역학치료군 
에서 첫 1 년 동안 유두종의 성장속도가 의미 있게 감소하였고 이러한 효과는 3년 동안 유지되었다고 보고하였다. Dihematoporphyrinether를 이용한 광역학치료는 재발성 호흡기 유 두종증의 중증도 점수를 $50 \%$ 감소시켰으나 장기간의 과민성 (photosensitivity)이 발생하는 문제가 있었다.

Shikowitz 등 28)은 2005년 새로운 광감작제 meso-tetrahydroxyphenyl chlorin을 사용하여 광역학치료를 시행하였는 데 정상조직보다 인유두종바이러스에 광감각제가 더 많이 흡 수되며 배출이 빠른 새로운 특징을 가지고 있다.

광원으로는 $652 \mathrm{~nm}$ 파장의 다이오드 레이저가 사용되었으 며 레이저 조사 시간은 200 330초, 에너지는 60 100 J이었다. Parallel-arm controlled trial로서 레이저 수술 후 6개월째와 18 개월째에 광역학치료를 시행한 환자들을 서로 비교하였다. 15 명 환자 중 5명이 12 15개월간 재발이 없었으나 3 5년 후 재발하였다. 일부 환자들이지만 재발의 기간을 상당히 늘리 는 효과가 있었다. 광역학치료의 효과를 판단하기 위해서는 향후 양질의 연구가 더 많이 필요하다.

\section{Cis-retinoic acid}

Cis-retinoic acid는 vitamin A의 대사물로 20년 전부터 임 상적인 연구가 이루어져 왔다. 인유두종바이러스가 상피 세포 에 감염되는 것에 착안해서 cis-retinoic acid가 상피 조직에 서 증식을 억제하는 작용이 인유두종바이러스에서도 효과가 있을 것이라는 가설을 기반으로 한 것이다. ${ }^{29}$ 하지만 연구결과 에서 유두종증에서 치료 효과가 미비하여 더 이상 연구가 잘 행해지지 않고 있으며 현재에는 대부분 상피의 여드름 치료 제로 사용되고 있다. ${ }^{30)}$

\section{Bevacizumab}

혈관내피성장인자(vascular endothelial growth factor)는 재발성 호흡기 유두종증의 발달에서 중요한 요인으로 알려져 있다. Bevacizumab은 재조합 인간 단일클론 면역글로불린 $\mathrm{Gl}$ 항체(recombinant humanized monoclonal immunoglobulin G1 antibody)로서 혈관내피성장인자에 결합하여 수용체 의 활성을 막아서 억제하는 기능을 한다. Bevacizumab은 직 장과 대장암의 보조요법으로 주로 사용되고 있고 당뇨성 망 막증(diabetic retinopathy), 황반변성(macular degeneration) 등에도 사용되고 있다. Rogers 등 ${ }^{31)}$ 은 10 명의 소아를 대상으 로 한 연구에서 Potassium-titanyl-phosphate(KTP) 레이저 수술 후 bevacizumab $0.5 \mathrm{~mL}(1.25 \mathrm{mg})$ 를 병변내에 주입한 후 2 3주 간격으로 3회 실시하였다. 그 결과 수술 간격을 6주에 서 12 주로 향상, 치료 횟수를 연 8 회에서 4 회, 질병의 심각도 와 음성의 질 모두 유의미한 수준으로 향상됨을 보고 하였다.
이처럼 임상적으로 긍정적인 효과를 보고하였고, 200예의 치 료 동안 합병증이 없어서 향후 유용한 보조요법이 될 가능성 이 있어 연구가 더 필요하다.

\section{Cidofovir}

Cidofovir는 cytosine 유사체로서 헤르페스바이러스, 아데 노바이러스, 인유두종바이러스, 거대세포바이러스들과 같은 DNA 바이러스의 항바이러스 약물로 가장 흔히 사용되고 있 다. Cidofovir는 바이러스의 핵산 생성을 억제하여 항바이러 스 작용을 한다. 인유두종바이러스 백신이 개발되기 전까지 가 장 흔히 사용되는 보조요법이었다.

투여 방법은 병변에 국소적으로 주사하며 적정한 용량과 농도에 대해서는 논란이 있다. Clamp와 Saunders ${ }^{32}$ 에 의한 체계적 고찰에 따르면 소아과 어른 환자에서 사용된 농도는 0.0001 에서 $37.5 \mathrm{mg} / \mathrm{mL}$ 로 다양했으며, 약 $42 \%$ 의 논문들에 서 $5 \mathrm{mg} / \mathrm{mL}$ 의 농도를 사용하였다. Derkay 등 33$)$ 은 농도는 $2.5 \sim 7.5 \mathrm{mg} / \mathrm{mL}$, 총량은 $3 \mathrm{mg} / \mathrm{kg}$ 이하로 사용할 것을 권고 하였다. 또 Pransky 등 ${ }^{34}$ 에 따르면 소아 환자들은 기도가 좁 아서 주사 후 부종으로 인해 기도가 막힐 위험성이 있어 투여 량이 제한적이어야 하기 때문에 농도를 어른보다 더 높게 사 용해야 한다고 하였으며, 특히 영아에서는 기도 폐쇄의 위험성 이 더 높다고 하였다.

투여 횟수도 불분명한데 Pransky 등 ${ }^{34}$ 은 2 4주 간격의 짧 은 주기로 반복하는 것이 가장 효과적이라고 하였고, 반면에 Naiman 등 ${ }^{35)}$ 은 한 달 이내의 간격으로 주사하는 것은 효과가 덜 하다고 하였다. 재발성 호흡기 유두종증의 임상적 중증도 가 개인별로 다르기 때문에 환자에게 맞추어서 횟수를 조절 할 필요가 있다.

Chadha와 James ${ }^{36}$ 의 체계적 문헌 고찰에 포함된 이중맹 검 위약 대조군 연구의 $57 \%$ 에서 완전 관해, $35 \%$ 에서 부분 관 해가 있다고 보고하였다. 환자 연령별과 시간별로 cidofovir 의 농도가 다르게 사용되었기 때문에 방법의 일관성이 부족한 단점이 있는 연구이다. 질병의 심각도, 삶의 질, 음성의 질에서 향상이 있다는 보고들도 있었지만 통계적으로 유의한 수준의 차이는 없었다.

항바이러스제는 전신 투여 시에 구토나, 구역, 복통, 간염 등 의 합병증들이 있지만 국소적 투여 시에는 이러한 부작용이 없다. 그리고 장기간 사용할 경우 동물 실험에서 나타난 악성 화 가능성에 대해서도 아직 불확실한 위험성이 있다. Cidofovir도 일부 환자들에게서 긍정적인 효과가 있다는 보고들이 있기 때문에 임상에서 주의해서 사용해 볼 수 있는 보조요법 이다. 


\section{결 론}

아직 확실한 치료 방법이 없는 재발성 호흡기 유두종증의 여러가지 보조요법들의 연구 결과들이 다양하게 보고되고 있 기 때문에 대규모의 맹검 연구나 전향적 연구가 필요하지만 유병률이 낮기 때문에 시행하기에 어려움이 있다. 하지만 중 증도가 심하거나 재발이 흔할 경우에는 환자의 삶의 질과 호 흡 유지를 위해 보조요법을 적극적으로 시행할 필요가 있으 며, 향후 더 많은 연구가 필요한 분야이다.

중심 단어: 보조요법, 인유두종바이러스, 재발성 호흡기 유두 종증, 유두종바이러스 백신.

\section{Acknowledgments}

This study was supported by research funds from Dong-A University.

\section{Conflicts of Interest}

The author has no financial conflicts of interest.

\section{REFERENCES}

1. Marsico M, Mehta V, Chastek B, Liaw KL, Derkay C. Estimating the incidence and prevalence of juvenile-onset recurrent respiratory papillomatosis in publicly and privately insured claims databases in the United States. Sex Transm Dis 2014;41(5):300-5.

2. Venkatesan NN, Pine HS, Underbrink MP. Recurrent respiratory papillomatosis. Otolaryngol Clin North Am 2012;45(3):671-94, viii-ix.

3. Taliercio S, Cespedes M, Born H, Ruiz R, Roof S, Amin MR, et al. Adult-onset recurrent respiratory papillomatosis: a review of disease pathogenesis and implications for patient counseling. JAMA Otolaryngol Head Neck Surg 2015;141(1):78-83.

4. Corbitt G, Zarod AP, Arrand JR, Longson M, Farrington WT. Human papillomavirus (HPV) genotypes associated with laryngeal papilloma. J Clin Pathol 1988;41(3):284-8.

5. Rabah R, Lancaster WD, Thomas R, Gregoire L. Human papillomavirus-11-associated recurrent respiratory papillomatosis is more aggressive than human papillomavirus-6-associated disease. Pediatr Dev Pathol 2001;4(1):68-72.

6. Schraff S, Derkay CS, Burke B, Lawson L. American Society of Pediatric Otolaryngology members' experience with recurrent respiratory papillomatosis and the use of adjuvant therapy. Arch Otolaryngol Head Neck Surg 2004;130(9):1039-42.

7. Fortes HR, von Ranke FM, Escuissato DL, Araujo Neto CA, Zanetti G, Hochhegger B, et al. Recurrent respiratory papillomatosis: a stateof-the-art review. Respir Med 2017;126:116-21.

8. Limsukon A, Susanto I, Soo Hoo GW, Dubinett SM, Batra RK. Regression of recurrent respiratory papillomatosis with celecoxib and erlotinib combination therapy. Chest 2009;136(3):924-6.

9. Holland BW, Koufman JA, Postma GN, McGuirt WF Jr. Laryngopharyngeal reflux and laryngeal web formation in patients with pediatric recurrent respiratory papillomas. Laryngoscope 2002;112(11):1926-9.

10. Borkowski G, Sommer P, Stark T, Sudhoff H, Luckhaupt H. Recurrent respiratory papillomatosis associated with gastroesophageal reflux disease in children. Eur Arch Otorhinolaryngol 1999;256(7):370-2.

11. Harcourt JP, Worley G, Leighton SE. Cimetidine treatment for recurrent respiratory papillomatosis. Int J Pediatr Otorhinolaryngol 1999; 51(2):109-13.

12. McKenna M, Brodsky L. Extraesophageal acid reflux and recurrent respiratory papilloma in children. Int J Pediatr Otorhinolaryngol 2005;
69(5):597-605.

13. Pashley NR. Can mumps vaccine induce remission in recurrent respiratory papilloma?. Arch Otolaryngol Head Neck Surg 2002;128(7): 783-6.

14. Lei J, Yu W, Yuexin L, Qi C, Xiumin S, Tianyu Z. Topical measlesmumps-rubella vaccine in the treatment of recurrent respiratory papillomatosis: results of a preliminary randomized, controlled trial. Ear Nose Throat J 2012;91(4):174-5.

15. Wang Y, Dai PD, Zhang TY. Experimental research on the therapeutic effect of MMR vaccine to juvenile-onset recurrent respiratory papillomatosis. Eur Arch Otorhinolaryngol 2019;276(3):801-3.

16. Meacham RK, Thompson JW. Comparison of cidofovir and the measles, mumps, and rubella vaccine in the treatment of recurrent respiratory papillomatosis. Ear Nose Throat J 2017;96(2):69-74.

17. Leventhal BG, Kashima HK, Weck PW, Mounts P, Whisnant JK, Clark KL, et al. Randomized surgical adjuvant trial of interferon alfa-n1 in recurrent papillomatosis. Arch Otolaryngol Head Neck Surg 1988;114(10):1163-9.

18. Lee JH, Smith RJ. Recurrent respiratory papillomatosis: pathogenesis to treatment. Curr Opin Otolaryngol Head Neck Surg 2005;13(6):354-9.

19. Maunsell R, Bellomo-Brandão MA. Pegylated interferon for treating severe recurrent respiratory papillomatosis in a child: case report. Sao Paulo Med J 2018;136(4):376-81

20. Healy GB, Gelber RD, Trowbridge AL, Grundfast KM, Ruben RJ, Price KN. Treatment of recurrent respiratory papillomatosis with human leukocyte interferon. Results of a multicenter randomized clinical trial. N Engl J Med 1988;319(7):401-7.

21. Suter-Montano T, Montaño E, Martínez C, Plascencia T, Sepulveda MT, Rodríguez M. Adult recurrent respirator papillomatosis: a new therapeutic approach with pegylated interferon alpha $2 \mathrm{a}$ (Peg-IFNa2a) and GM-CSF. Otolaryngol Head Neck Surg 2013;148(2):253-60.

22. Gerein V, Rastorguev E, Gerein J, Jecker P, Pfister H. Use of interferon-alpha in recurrent respiratory papillomatosis: 20-year follow-up. Ann Otol Rhinol Laryngol 2005;114(6):463-71.

23. Szeps M, Dahlgren L, Aaltonen LM, Öhd J, Kanter-Lewenshon L, Dahlstrand $\mathrm{H}$, et al. Human papillomavirus, viral load and proliferation rate in recurrent respiratory papillomatosis in response to alpha interferon treatment. J Gen Virol 2005;86(Pt 6):1695-702.

24. Foldvari M, Kumar P. Recent progress in the application of nanotechnology for prevention and treatment of human papillomavirus infection. Ther Deliv 2012;3(8):1005-17.

25. Dion GR, Teng S, Boyd LR, Northam A, Mason-Apps C, Vieira D, et al. Adjuvant human papillomavirus vaccination for secondary prevention: a systematic review. JAMA Otolaryngol Head Neck Surg 2017;143(6):614-22.

26. Mészner Z, Jankovics I, Nagy A, Gerlinger I, Katona G. Recurrent laryngeal papillomatosis with oesophageal involvement in a 2 year old boy: successful treatment with the quadrivalent human papillomatosis vaccine. Int J Pediatr Otorhinolaryngol 2015;79(2):262-6.

27. Shikowitz MJ, Abramson AL, Freeman K, Steinberg BM, Nouri M. Efficacy of DHE photodynamic therapy for respiratory papillomatosis: immediate and long-term results. Laryngoscope 1998;108(7):962-7.

28. Shikowitz MJ, Abramson AL, Steinberg BM, DeVoti J, Bonagura VR, Mullooly V, et al. Clinical trial of photodynamic therapy with mesotetra (hydroxyphenyl) chlorin for respiratory papillomatosis. Arch Otolaryngol Head Neck Surg 2005;131(2):99-105.

29. Bell R, Hong WK, Itri LM, McDonald G, Strong MS. The use of cisretinoic acid in recurrent respiratory papillomatosis of the larynx: a randomized pilot study. Am J Otolaryngol 1988;9(4):161-4.

30. Lippman SM, Donovan DT, Frankenthaler RA, Weber RS, Earley CL, Hong WK, et al. 13-Cis-retinoic acid plus interferon-alpha $2 \mathrm{a}$ in recurrent respiratory papillomatosis. J Natl Cancer Inst 1994;86(11): 859-61.

31. Rogers DJ, Ojha S, Maurer R, Hartnick CJ. Use of adjuvant intrale- 
sional bevacizumab for aggressive respiratory papillomatosis in children. JAMA Otolaryngol Head Neck Surg 2013;139(5):496-501.

32. Clamp PJ, Saunders MW. Systematic review of intralesional cidofovir dosing regimens in the treatment of recurrent respiratory papillomatosis. Int J Pediatr Otorhinolaryngol 2013;77(3):323-8.

33. Derkay CS, Volsky PG, Rosen CA, Pransky SM, McMurray JS, Chadha NK, et al. Current use of intralesional cidofovir for recurrent respiratory papillomatosis. Laryngoscope 2013;123(3):705-12.
34. Pransky SM, Magit AE, Kearns DB, Kang DR, Duncan NO. Intralesional cidofovir for recurrent respiratory papillomatosis in children. Arch Otolaryngol Head Neck Surg 1999;125(10):1143-8.

35. Naiman AN, Ceruse P, Coulombeau B, Froehlich P. Intralesional cidofovir and surgical excision for laryngeal papillomatosis. Laryngoscope 2003;113(12):2174-81.

36. Chadha NK, James A. Adjuvant antiviral therapy for recurrent respiratory papillomatosis. Cochrane Database Syst Rev 2010;(1):CD005053. 